\title{
Market Efficiency Indicators in Marine Fish Marketing in Goa, India
}

\author{
P. S. Swathi Lekshmi ${ }^{1}$, R. Narayanakumar ${ }^{2} \&$ Shyam S. Salim $^{3}$ \\ ${ }^{1}$ ICAR-Vizhinjam Research Centre of CMFRI, Thiruvananthapuram, Kerala, India \\ ${ }^{2}$ ICAR-Madras Research Centre of CMFRI, CIBA Campus, Chennai, Tamil Nadu, India \\ ${ }^{3}$ ICAR-Central Marine Fisheries Research Institute, Kochi, India \\ Correspondence: ICAR-Vizhinjam Research Centre of CMFRI, Vizhinjam, Post Box No. 9, Vizhinjam P.O., \\ Thiruvananthapuram 695521, Kerala, India. Tel: 91-471-248-0224. E-mail: swathi.lekshmi263@gmail.com
}

Received: November 12, 2019

Accepted: March 15, $2020 \quad$ Online Published: May 15, 2020

doi:10.5539/jas.v12n7p112

URL: https://doi.org/10.5539/jas.v12n7p112

\begin{abstract}
The Indian State of Goa has a coastal length of $104 \mathrm{Kms}$ and the State contributes $1.85 \%$ to the marine fish production of the country. A study was conducted to assess the market efficiency indicators such as Gross Marketing Margin, Percentage Share of Fisherman in the Consumers Rupee (PSFCR) and the Coefficient of variation. The study revealed that high value fishes such as cobia, silver Whiting, seer fishes, prawns and milk shark recorded a comparatively higher price spread. Varieties which recorded higher PSFCR were speckled prawn $(72.86 \%)$, cobia $(70.31 \%)$, seerfish $(69.98 \%)$, Brown shrimps or ginga prawns $(69.43 \%)$, pony fish $(67.58 \%)$ and milk shark (65.61\%). At the point of first sales, high value fishes such as cobia, seerfishes, prawns and silver biddy had a co-efficient of variation of less than $10 \%$ indicating a higher price stability. High value fishes such as ribbon fishes, seerfishes, cobia, indian white prawn, barracudas, brown prawns, speckled prawns, kadal shrimps and half beaks were among the list of fishes which recorded a low co-efficient of variation of less than $10 \%$ at the point of last sales.
\end{abstract}

Keywords: market efficiency indicators, price spread, price stability

\section{Introduction}

Fish is a highly perishable commodity and hence the time interval required to reach the consumer once it is landed, is of paramount importance (Getu, Misganaw, \& Bazezew, 2015). For this, an efficient fish marketing system has to be in place, which caters to the nutritional requirements of the general populace, as well as the demands of the export market. An efficient fish marketing system reduces post-harvest losses, employs a substantial section of the workforce while generating revenue for the country (Akande \& Diei-Ouadi, 2010; Kumar et al., 2008; Ali et al., 2014). In the present context of diminishing fish catch and increase in prices, it is imperative that an efficient fish marketing system has to be developed if we have to safeguard the interests of the fishermen as well as ensure a steady supply of fresh fish to the consumers (Sathiadhas et al., 2012). There is an increasing consumer awareness on the health benefits of fish as a protein food when compared to other forms of animal protein (Salim et al., 2015; Henchion et al., 2017). India is the second largest fish producer in the world with a total production of 13.7 million metric tonnes in 2018-19 (Government of India, 2019a). The sector contributes to 1\% of the Gross Domestic Product (GDP) and 5.23\% of the Agricultural GDP (Anonymous, 2019; Government of India, 2019b). One of the major thrust areas in realizing the "Blue revolution" in the country is the development of fish markets, cold storage chains, fish transport facilities and facilities for fish processing apart from providing and fine tuning of infrastructural facilities at the harbor (NFDB, 2018). All these are bound to give a major fillip to the fisheries sector in the country. Fish is the staple food of the Goan population. Fishing takes the third position in line after, mining and tourism contributing to the economy of the State. The State has enormous scope for fisheries production namely in the marine, brackish and fresh water sectors. About $9.7 \%$ of the Goan population is dependent on fisheries sector for their livelihood. The state has an active fishermen population of 11,944 (Directorate of Fisheries, 2014). A total of 14,081 fishers are involved in fish marketing, $96 \%$ of which were women (Srikanth et al., 2015).

The foregoing study attempts to study the market efficiency indicators in the State of Goa. Goa has a coastal length of $104 \mathrm{kms}$ and comprises of two coastal districts namely, South Goa and North Goa with a total of 39 marine fishing villages, of which majority (23) are situated in South Goa. The State has 2,189 fisher families 
(Marine Fisheries Census, 2010). The marine fish landings of Goa in 2018 was to the tune of 0.59 lakh tonnes. The estimate of the value of marine fish landings in Goa was Rs. 920 crores at the landing center and Rs. 1312 crores at the Retail center in the year 2018 (FRAD \& CMFRI, 2019). The Fisheries sector contributes to $2.5 \%$ of the whole gross domestic product and $17.1 \%$ of the agriculture gross domestic product of Goa. The contribution of the State to the total marine fish landings of the country was $1.85 \%$ (http://goa.pscnotes.com). Against this background, it was decided to study the market efficiency indicators.

Market efficiency relates to the extent to which actual market prices reflect the true production costs and benefits received from output (Formosa, 2008; Hilda, 2016). The market efficiency indicators used for the present study were Gross Marketing Margin (GMM) and Percentage Share of Fishermen in the Consumers Rupee (PSFCR) and Co-efficient of Variation.

\section{Materials and Methods}

South Goa which harbours the largest number of fishing villages (23) and largest number of fishermen population (6721) was selected for the study. Besides this district has the largest number of fisher folk (953) involved in the marketing of fish. Data pertaining to the market prices of marine fishes were collected from the largest landing center in South Goa namely, Cutbona (Colaco, 2019) from the largest wholesale market at Margao and from the Retail market at Vasco and from tertiary markets on a weekly basis during the year 2013-14. Gross Marketing Margin (GMM) and Percentage Share of Fishermen in Consumers Rupee (PSFCR) were used for studying the price behavior (Sathiadhas et al., 2011). The Gross Marketing Margin or Price Spread is the difference between the price received by the producer (price at landing center) and price paid by the consumer (Retail market price) for any given commodity at a particular point of time in the market.

$$
\begin{gathered}
\text { Gross Marketing Margin }(\mathrm{GMM})=\text { Retail Price }(\mathrm{RP})-\text { Landing Centre Price }(\mathrm{LP}) \\
\text { Percentage Share of fishermen in the consumer Rupee }(\mathrm{PSFCR})=\mathrm{LP} / \mathrm{RP} \times 100
\end{gathered}
$$

The price stability was analysed using coefficient of variation $(\mathrm{CV})$ : $\mathrm{CV}=($ Standard deviation/Mean $) \times 100$.

\section{Results and Discussion}

Fish eating population in India is $60 \%$ of the total population (Salim, 2016). The per capita consumption of fish in the country is $8.49 \mathrm{Kg}$. Contribution of the State of Goa to the marine fish landings in the country is $1.85 \%$ of the total marine landings of the country (CMFRI, 2013). All households in rural Goa eat fish, whereas in urban households it is 893 per 1000 households (The Times of India, 2014). Thus fish is the staple food of the Goan population. Goa has a well-established system of fish markets both in rural as well as in urban areas. The boat owners sell the fish as soon as it is landed, directly to wholesalers or commission agents who in turn sell them to retailers. Most often, the commission agents, wholesalers-cum agents and wholesalers do not sell directly to consumers except to bulk buyers such as hostels, restaurants, hotels and exporting companies. Goa has a tremendous influx of tourists throughout the year and hence fish occupies a premium place in the hotel menu. If not sold to hotels, wholesalers sell the fish to retailers and vendors who come to the wholesale market and purchase fish either at auction or directly. When the fish production is scarce, it is directly sold to consumers by fishermen. When the wholesalers or agents buy fish directly from the fishermen, they enter into a contract with the exporting units, hotels, etc. During the monsoon season when there is less fish availability, the wholesalers sell the iced fish which he has purchased or stocked in the freezers during peak season. He sells it to the fisher folk, or hotels at an exorbitant price, thereby taking a lions share of the profit. Thus, the role of the fishermen recedes to the background allowing the numerous middleman to cash in profits. Fish processors sell most of their fish products to fish brokers in large cities at a very less price. The brokers, in turn, sell the products to restaurants at a high price which includes their commission. The restaurants and hotels price the fish items in the menu card still higher and by the time it reaches the ultimate consumer, the price is four times more than the actual cost of the product. For the present study the marketing efficiency was studied in terms of the price spread, Producers share in consumers rupee and the market stability which is presented in Table 1. 
Table 1. Market efficiency indicators in fish marketing in Goa

\begin{tabular}{|c|c|c|c|c|c|}
\hline Sl.No. & Fish varieties & $\begin{array}{l}\text { Average Gross } \\
\text { Marketing Margin } \\
\text { (GMM) Rs. } \mathrm{Kg}^{-1}\end{array}$ & $\begin{array}{l}\text { Average Percentage Share } \\
\text { of Fishermen in Consumers } \\
\text { Rupee (PSFCR) \% }\end{array}$ & $\begin{array}{l}\text { Co-efficient of } \\
\text { Variation at the } \\
\text { point of first sales }\end{array}$ & $\begin{array}{l}\text { Co-efficient of } \\
\text { Variation at the } \\
\text { point of last sales }\end{array}$ \\
\hline 1. & Milk Shark & 108 & 65.61 & 21.13 & 15.37 \\
\hline 2. & Rays & 78 & 54.14 & 12.45 & 13.01 \\
\hline 3. & Cat fish & 59 & 45.89 & 26.59 & 20.88 \\
\hline 4. & Dorab Wolf Herring & 96 & 53.87 & 7.71 & 8.42 \\
\hline 5. & Oilsardine & 37 & 34.49 & 9.88 & 14.58 \\
\hline 6. & Rainbow sardine & 29 & 37.92 & 10.89 & 12.37 \\
\hline 7. & Hilsha Shad & 48 & 37.93 & 15.67 & 16.37 \\
\hline 8. & Greater Lizard fish & 59 & 54.44 & 14.04 & 7.48 \\
\hline 9. & Half beaks & 70 & 62.10 & 21.03 & 7.23 \\
\hline 10. & Full beaks & 54 & 54.38 & 23.51 & 12.12 \\
\hline 11. & Threadfin breams & 58 & 43.10 & 16.73 & 16.98 \\
\hline 12. & Croakers & 71 & 47.03 & 28.36 & 23.41 \\
\hline 13. & Ribbonfishes & 65 & 59.61 & 8.78 & 0.76 \\
\hline 14. & Horse Mackerel & 55 & 40.16 & 18.42 & 13.16 \\
\hline 15. & Indian Scad & 29 & 38.30 & 17.20 & 11.77 \\
\hline 16. & Six banded trevally & 24 & 31.11 & 17.14 & 10.50 \\
\hline 17. & Shrimp Scad & 57 & 43.49 & 6.79 & 10.50 \\
\hline 18. & Silver whitings & 231 & 63.39 & 7.48 & 30.18 \\
\hline 19. & Cobia & 291 & 70.31 & 3.82 & 3.46 \\
\hline 20. & Pony fish & 24 & 67.58 & 27.02 & 11.02 \\
\hline 21. & False trevally & 78 & 54.99 & 23.49 & 7.44 \\
\hline 22. & Indian Mackerel & 77 & 60.08 & 26.94 & 17.20 \\
\hline 23. & Seer fishes & 179 & 69.98 & 7.80 & 3.07 \\
\hline 24. & Tunnies & 68 & 53.50 & 17.08 & 5.96 \\
\hline 25. & Barracudas & 67 & 43.76 & 19.53 & 5.94 \\
\hline 26. & Whipfin Silver Biddy & 94 & 49.10 & 6.92 & 13.69 \\
\hline 27. & Tongue sole & 48 & 35.00 & 47.93 & 15.25 \\
\hline 28. & Malabar Tongue sole & 62 & 50.75 & 32.39 & 13.82 \\
\hline 29. & Ginga Prawn/Brown shrimps & 101 & 69.43 & 8.65 & 6.19 \\
\hline 30. & Kadal shrimps & 78 & 63.10 & 9.96 & 9.55 \\
\hline 31. & Speckled prawn & 124 & 72.86 & 14.28 & 8.08 \\
\hline 32. & Kiddi shrimp & 71 & 52.87 & 12.72 & 14.63 \\
\hline 33. & Indian White Prawn & 169 & 73.55 & 17.63 & 5.02 \\
\hline 34. & Crabs & 72 & 48.80 & 13.33 & 9.11 \\
\hline 35. & Cephalopods & 97 & 64.39 & 19.13 & 11.75 \\
\hline
\end{tabular}

Note. 1US \$ $=71.14$ Indian Rupee (Rs.)

Price Spread or Gross Marketing Margin is the difference in the price paid by the consumer and the price paid by the producer, for a particular fish species at a given point of time in the market. Narayanakumar and Sathiadhas (2006) have studied the marketing efficiency in terms of Price Spread or Gross Marketing Margin. According to them, a market can be graded as efficient only if the price spread is minimum. The average price spread for different varieties of fish ranged from Rs. $24 \mathrm{Kg}^{-1}$ for fishes like Six banded trevally, Pony fish to as high as Rs. $291 \mathrm{Kg}^{-1}$ for fishes like Cobia. Varieties such as Silver Whiting (Rs. $231 \mathrm{Kg}^{-1}$ ), Seer fishes (Rs. $179 \mathrm{Kg}^{-1}$ ), Indian White Prawn (Rs. $169 \mathrm{Kg}^{-1}$ ), Speckled Prawn (Rs. $124 \mathrm{Kg}^{-1}$ ), Milk Shark (Rs. $108 \mathrm{Kg}^{-1}$ ) and Ginga Prawn or Brown Shrimps (Rs. $101 \mathrm{Kg}^{-1}$ ) recorded a comparatively higher price spread. The higher price spread. Solanke et al. (2013) in their studies on the price spread analysis of farmed shrimp in Thane district of Maharashtra said that, in a situation of higher price spread, higher marketing cost and margin are covered by intermediaries in the marketing channel. Aswathy et al. (2014) in her study on the efficiency of domestic fish marketing in Kerala observed that, marketing margin per $\mathrm{Kg}$ of fish was highest for seer fish Rs. $118 \mathrm{Kg}^{-1}$. Sathiadhas et al. (2011) observed that, the higher price spread for certain fish varieties was attributed to the additional cost incurred during processing, value addition or post-harvest operations.

\subsection{Percentage Share of Fisherman in the Consumers Rupee (PSFCR)}

As could be observed from Table 1, the Percentage share of Fisherman in the Consumers Rupee ranged from $31.11 \%$ in the case of six banded trevally to $73.55 \%$ in the case of Indian White Prawn. In a similar study 
conducted by Kaygisiz and Eken (2018), the PSFCR of fish varieties ranged from 39.95 to $66.67 \%$. Varieties which recorded higher PSFCR were speckled prawn $(72.86 \%)$, Cobia $(70.31 \%)$, Seerfish $(69.98 \%)$, Brown shrimps or Ginga prawns (69.43\%), pony fish (67.58\%) and Milk Shark (65.61\%). Sathiadhas et al. (2011) in a similar study observed that varieties such as Sharks, Seerfish and Mackerel recorded a comparatively higher PSFCR of 77.12, 75.22, and 71.29\% respectively. They attribute the higher share of fisherman in the consumers rupee due to absence of middlemen in the marketing channel which denotes a higher degree of market efficiency (Das et al., 2013). In a study conducted by Upadhyay, Jagpal, and Roy (2016), it was observed that, higher marketing margins were claimed by the intermediaries, further reducing the market efficiency. Aswathy et al.'s. (2014) study on the marketing efficiency in the fish markets of the Southern State of Kerala reported that, in the local marketing Channel, Seerishes, Pomfrets and Mackerel had the highest PSFCR to the tune of 70.00, 67.11 and 66.30 respectively.

\subsection{Price Stability}

Fish prices vary across seasons, days and markets as well as time. Sathiadhas et al. (2011) have opined on the spatial and temporal variations in marine fish price. According to him the same fish variety would command different prices in the same market at the beginning of the day as well as when the market draws to a close. A market is said to be efficient when there is a high degree of stability in the fish prices, spatially and temporally. The price stability for the following study was worked out by working out the co-efficient of variation (CV) between the point of first sales and the point of last sales (Table 1).

It is observed that at the point of first sales, high value fishes such as Cobia, Seerfishes, prawns and Silver biddy had a co-efficient of variation of less than $10 \%$. On the other hand fishes such as Tongue sole, Malabar tongue sole, croakers and Pony fish had a relatively high co-efficient of variation $(47.93,32.39,28.36$ and 27.02 respectively). Evidently such fishes had lesser price stability at the point of first sales. Aswathy and Samad (2013) observed in their study that,rock cods registered the highest fluctuation in prices at the landing center ie point of first sales and lizard fishes, on the other hand, fetched the lowest price fluctuations.

High value fishes such as Ribbon fishes, Seerfishes, Cobia, Indian white prawn, Barracudas, Brown prawns, speckled prawns, Kadal shrimps and half beaks were among the list of fishes which recorded a low co-efficient of variation of less than $10 \%$ at the point of last sales. Few high value fishes such as Brown shrimp, Kadal shrimps, Seerfishes, Cobia, and Ribbon fishes had a low co-efficient of variation of less than $10 \%$ at both first and last point of sales.

\section{Conclusion}

Marine Fish has become an important item of trade in the domestic and international arena. A fish marketing system is considered efficient only when the fish in its fresh state is made available to the consumers, distributed across the length and breadth of the country in the minimum time gap. Most of the marine high value fishes which are exported include, shrimp, lobster, cuttlefish, squid certain types of finfishes which constitute the bulk of marine exports from the country. These marine exports comprise $29 \%$ of the total fish landings in the country. The rest $70 \%$ of fish channelized in the domestic supply chain in the country suffers from major lacunae such as lack of well-organized infrastructural facilities such as cold storage systems in all the landing centers, harbours and also during transit as well in storage and markets. Though market extension, integration and expansion has registered a fillip when compared to earlier times, the percentage share of fisherman in consumers rupee is high only for a few high value fishes on which fishermen depend for a lions share of their income. Dominance of middle men and intermediaries in the marketing chain result in low market efficiency. Institutional mechanisms and proper ice, storage facilities both at landing centers, markets and during transit will go a long way in reducing post-harvest losses and ensuring a remunerative price for the producers and fishermen at large.

\section{References}

Akande, G., \& Diei-Ouadi, Y. (2010). Post-harvest losses in small-scale fisheries. Case studies in five sub-Saharan African countries.

Ali, M. M., Rahman, M. M., Hossain, M. Y., Rahman, M. Z., Hossen, M. A., Naser, S. M. A., Hoque, M. A. (2014). Fish marketing system in southern Bangladesh: recommendations for efficient marketing. Our Nature, 12(1), 28-36. https://doi.org/10.3126/on.v12i1.12254

Anonymous. (2019). Fisheries sector registered more than double growth in past 5 years; emerged largest group in agri export. The Economic Times.

Aswathy, N., \& Abdussamad, E. M. (2013). Price Behaviour and marketing efficiency of Marine Fish in Tuticorin, Tamil Nadu. Journal of Fisheries Economics and Development, 13(2), 29-35. 
CMFRI. (2013). CMFRI Annual Report 2011-2012. Technical Report. CMFRI, Kochi.

Colaco, V. (2019). An Analysis of LED Ban in Fishing Industry—Case study of Cutbona Jetty (Goa). Acta Scientific Agriculture, 3(3), 4-10.

Das, A., Upadhayay, A. D., Kumar, N. R., Prakash, S., Debnath, B., \& Datta, M. (2013). Marketing Profile of selected fish markets in Tripura. Agricultural Economics Research Review, 26(1), 115-120.

Directorate of Fisheries, Goa. (2014). Statistics. Goa Fisheries at a Glance. Retrieved from https://fisheries.goa. gov.in/? page_id=131\#

Formosa, I. (2008). Measuring Market Efficiency: A Comparative Study. Bank of Valletta Review, 38, 8.

FRAD \& CMFRI. (2019). Marine Fish Landings in India, 2018. Technical Report, CMFRI, Kochi.

Getu, A., Misganaw, K., \& Bazezew, M. (2015). Post-harvesting and Major Related Problems of Fish Production. Fish Aquac J, 6, 154. https://doi.org/10.4172/2150-3508.1000154

Government of India. (2019a). Economic Survey 2018-19. Government of India, Ministry of Finance Department of Economic Affairs Economic Division, New Delhi, India.

Government of India. (2019b). Fish Production and Consumption. Press Information Bureau, Government of India, Ministry of Agriculture and Farmers Welfare, New Delhi, India.

Henchion, M., Hayes, M., Mullen, A. M., Fenelon, M., \& Tiwari, B. (2017). Future Protein Supply and Demand: Strategies and Factors Influencing a Sustainable Equilibrium. Foods, 6(7), 53. https://doi.org/10.3390/ foods6070053

Hilda, E. I. (2016). Assessment of the Efficiency of Fish Marketing Channels in the Lake Kainji Inland Fisheries and along Nigeria-Niger Border (p. 30, MSc.Thesis, Department of Aquaculture and Fisheries Management, Faculty of Agriculture and Forestry, University of Ibadan, Nigeria).

Kaygisiz, F., \& Eken, M. (2018). A Research on Determination of Fish Marketing Margins in Istanbul Province of Turkey. Turkish Journal of Fisheries and Aquatic Sciences, 18, 801-807. https://doi.org/10.4194/ 1303-2712-v18_6_06

Kumar, G., Datta, K. K., Joshi, P. K., Katiha, P. K., Suresh, R., Ravisankar, T., ... Muktha, M. (2008). Domestic fish marketing in India-Changing structure, conduct, performance and policies. Agricultural Economics Research Review, 21, 345-354.

Narayanakumar, R., \& Sathiadhas, R. (2006). Domestic fish marketing opportunities for marine fisheries sector in India. Proceedings of the National Workshop on Post-harvest Methods and Domestic Fish Marketing Opportunities (pp. 59-67).

NFDB (National Fisheries Development Board). (2018). Blue Revolution-An Overview (p. 1). National Fisheries Development Board, Department of Animal Husbandry, Dairying, and Fisheries, Ministry of Agriculture and Farmers Welfare, Government of India.

Salim, S. S. (2016). Fish Consumption Pattern in India, Exports-Overview. Food and Beverage News (August $1-15,2016$, p. 25).

Salim, S. S., Safeena, P. K., \& Athira, N. R. (2015). Does India really need to Export Fish: Reflections and Upshots. Agricultural Economics Research Review, 28, 117-126. https://doi.org/10.5958/0974-0279.2015. 00027.0

Sathiadhas, R., Narayanakumar, R., \& Aswathy, N. (2011). Efficiency of domestic marine fish marketing in India-A macroanalysis. Indian Journal of Fisheries, 58(4), 125-131.

Sathiadhas, R., Narayanakumar, R., \& Aswathy, N. (2012). Marine Fish Marketing in India (p. 276). Central Marine Fisheries Research Institute, Kochi.

Sreekanth, G. B., Manju Lekshmi, N., \& Narendra, P. S. (2015). Catch Trends in Major Marine Fisheries Resources of Goa. Technical Bulletin No. 49. ICAR-ICAR Research Complex for Goa (Indian Council of Agricultural Research), Goa, India.

The Times of India. (2014). The Times of India (September 4, 2014).

Upadhyay, A. D., Jagpal, \& Roy, P. D. (2016). Structural performance of fish market and socio-economic status of market functionaries of Naveen Machhali Mandi Mahanva of Gorakhpur, Uttar Pradesh. Economic Affairs, 61(3), 511-518. https://doi.org/10.5958/0976-4666.2016.00064.4 


\section{Copyrights}

Copyright for this article is retained by the author(s), with first publication rights granted to the journal.

This is an open-access article distributed under the terms and conditions of the Creative Commons Attribution license (http://creativecommons.org/licenses/by/4.0/). 